\title{
A Review of the Research on Childminding: Understanding Children's Experiences in Home-Based Childcare Settings
}

\author{
Lynn Ang' ${ }^{1}$ - Elizabeth Brooker ${ }^{1} \cdot$ Christine Stephen $^{2}$
}

Published online: 9 February 2016

(c) The Author(s) 2016. This article is published with open access at Springerlink.com

\begin{abstract}
This paper offers a discussion of the literature of an under-developed area of early years research-the exploration of childminding or home-based childcare and the contribution which this form of provision makes for children and families. Despite growing interest in childminding at the policy level and some international research on understanding home-based childcare settings and practices, there remains a relative dearth of studies conceptualising and reviewing the extant literature. This paper addresses this gap by presenting the findings of a comprehensive database search for literature and a review of published international work from 1990 to 2013. It offers a conceptual analysis of the notion of "home-based childcare", with a focus on understanding caregivers' practices, and the key issues and debates that characterise the field. The paper argues that home-based childcare not only offers a specialist type of service as family support, especially for vulnerable families, but that it provides a form of pedagogical approach to children's developmental and educational outcomes that is distinct from any other types of early years care.
\end{abstract}

Lynn Ang

1.ang@ioe.ac.uk

1 Department of Learning and Leadership, Institute of Education, University College London, 20 Bedford Way, London WC1H 0AL, UK

2 Institute of Education, University of Stirling, Scotland FK9 4LA, UK
Keywords Childminding - Home-based childcare . Children $\cdot$ Early years $\cdot$ Family day care

\section{Introduction}

Over the last decade, developments pertaining to early years provision and the child care needs of working parents have become an integral aspect of social and economic policy in England. The Children and Families bill (Department for Education [DfE] 2013), which aims to "encourage growth in the childcare sector" specifies an intention to "substantially increase the supply of high quality, affordable and available childcare and introduce childminding agencies to help more childminders into the market". The bill has been seminal in moving childminding, also known as home-based childcare, to the forefront of policy and research discussions. A key impetus is the drive towards the expansion of childminding services with greater autonomy for childminders to work independently and "operate and grow their business" (DfE 2013, p. 37).

Within this context, the purpose of this paper is to discuss the findings of a review of the research undertaken in the UK and internationally on home-based childcare-a term used in this paper to refer to a type of provision where the caregiver provides a service of paid care for a child or group of children in their own home. This arrangement would typically include preschool children aged from birth to 5 years, a group of mixed-age children, or at times older school-age children who attend as a form of after-school provision. Country profiles from OECD countries demonstrate that home-based childcare in countries such as the UK, France, Denmark, Italy and the Netherlands remains popular particularly with dual income families to supplement their childcare requirements (OECD 2006, 2012). 


\section{Methodology}

This paper is informed by a comprehensive review of literature on home-based childcare, that is non-parental, nonfamilial childcare arrangements offered in the provider's home. Gough et al. (2012) describe the process of reviewing literature as the art and science of collecting, analysing and synthesising different types of knowledge, essentially "learning from what others have already studied" (p. 1). Informed by this methodology, the research involves three primary activities: searching and identifying the relevant research, critically appraising and analysing the literature, and bringing together the different knowledge to construct an analytical discussion and critique. To set a manageable scope, the review was framed by three main questions:

1. What are the issues and debates that characterise research around home-based childcare?

2. What characteristics define effective home-based childcare?

3. What are the experiences of young children in homebased settings?

A first stage literature search was carried out using the following key descriptors: childminding, childminders, family day care, family child care, and home day care. The search entailed the use of the five research databases: Education and Resources in Education Index (ERIC), Taylor and Francis Educational Database, British Educational Index, Australian Education Index, and Educational Research Abstracts (ERA) Online. The inclusion criteria included those items published in the English language from 1990 to 2013 and a wide range of publication types: academic journals, government and third sector research reports, books, handbooks, manuals and guides for childminders. In addition, a few seminal studies carried out in the UK in the 1980s were included. The search produced 278 items from countries including the UK, US, Australia, New Zealand and Canada. The review process was then refined to identify papers that dealt substantially with childminding practices and which related more explicitly to the structural (e.g. child ratios, number of children, caregiver's qualifications) and process (e.g. caregiver practises, children's experiences and caregiver-child interactions) features that characterise childminding. A summary of the selected literature reviewed is provided in the "Appendix".

The search revealed significant variations in the descriptors used for home-based provision across countries. For example, literature from the US, Australia and New Zealand uses the phrase "family child care" or "family day care" to refer to a service of care for young children in a home setting, usually provided by a paid caregiver; although in a few cases, unpaid caregivers who are family members are also included (Arnett 1989; Bowes et al. 2009; Doherty et al. 2000; Hughes-Belding and Hegland 2012; Koh and Neuman 2009). In some European studies, the terms "in-home childcare" or "home care" are used while in the UK, the term "childminding" is commonly applied to paid, home-based care services that are provided by registered, independent providers in their own homes setting (Freeman and Karlsson 2012; Lekhal et al. 2011; Mooney and Statham 2003; OECD 2006). For the purpose of this paper, the terms childminding and home-based childcare are used synonymously, although it is important to problematize its conceptualisation and acknowledge that "home-based childcare" represents a range of organised care arrangements taking place either informally or formally when a child or group of children are cared for in the caregiver's domestic premises. It is also important to recognise that internationally, the organisational structures and systems of home-based childcare vary considerably according to country-specific policies and regulations. The review also revealed that research on home-based childcare practices is relatively recent, with sporadic studies emerging during the 1980s and early 1990s before the topic attracted wider interest. Since then, studies have been concerned with structural features and the role of homebased childcare within a mixed economy of provision, rather than the process, contextual day-to-day interactions experienced by children. The relative dearth of literature around process features serves to limit opportunities to generalise or draw conclusions about home-based practices. What it does demonstrate however, is the importance of establishing a summary review of extant understandings about home-based childcare practices, in order to better understand the knowledge base and gaps so that the relevant body of literature may be critiqued in meaningful ways.

\section{Reviewing the Literature}

There is established research which shows that the quality of the childcare and education environment play an important role in children's development (Policy Exchange 2013; UNESCO 2007, 2014). It is widely accepted from longitudinal studies conducted in the UK and the US that children's care and learning experiences during the early years are related to their later developmental outcomes (NICHD 2000; Sylva et al. 2004). However, we also know that the nature of the early years environment shows wide variation in terms of overall quality, children's experiences, caregivers' practices, and type of setting. 
Home-based childcare is distinct from any other type of provision. It offers specialised care with a single caregiver in the unique circumstances of the provider's own home. Research by Rusby et al. (2013), Bromer and Henly (2004), Fauth et al. (2012), Fuller et al. (2004) and others illustrates the potential for home-based childcare to serve as an effective provision to support young children and their families, and to exert a positive influence on children's early learning experience. For instance, a study by Rusby et al. (2013) involving 198 family childcare providers investigated the quality indicators of child care practices using the Child Care Ecology Inventory (CCEI) measures in the social domain. It showed that the quality of homebased caregivers' attitudes and child-interactions were associated with positive child social behaviour, and that this had implications for children's learning and school readiness. Research by Bromer and Henly (2004), and Fauth et al. (2012) demonstrated the potential of effective home-based settings to serve as a form of family support beyond the provision of direct childcare, while the empirical work undertaken by Fuller et al. (2004) on the differential quality between home-based and center-based settings indicated the propensity for home-based providers to better support the needs of low-income families who are in need of flexible childcare. These empirical findings have added to knowledge about home-based provision, but they also suggest the need to ensure a more nuanced analysis and interpretation of the evidence.

The following themes characterise the findings from this emerging body of research.

\section{Home-Based Childcare Offers Family Support, Especially for Vulnerable Families}

The very nature of home-based provision as care for young children in a home environment sets it apart from centrebased care. The research suggests that home-based caregivers are likely to provide a more personalised type of childcare, for instance, through the offer of care in a small group setting, flexible and extended hours to accommodate the needs of the family or parents, and the offer of more specialised services such as infant care (Fauth et al. 2012). There is evidence of the potential role of home-based childcare as a crucial form of family support, particularly for children and families in low-income or disadvantaged communities who may experience barriers to accessing centre-based services (Bromer and Henly 2004, 2009; Garrity and McGrath 2011; Koh and Neuman 2009; NCB 2011; Rusby et al. 2013). Bromer and Henly (2004) state that the depth of involvement of a childcare provider in a child's family contributes to a "more nuanced, multidimensional understanding of caregiving quality and its implications for children and family well being" (p. 942) and this has implications in particular for supporting the needs of disadvantaged families.

The literature describes a range of family support offered to parents, including emotional and personal support with parenting and family matters (Garrity and McGrath 2011; Hughes 1985), social support in terms of personal friendships and social networks (Monroe and Dunn 1999) and more instrumental and practical support such as offering information on education, employment and financial matters (Bromer 2002; Bromer and Henly 2009; Garrity and McGrath 2011; Hughes 1985). Both Hughes (1985) \& Bromer (2002) highlight the role of home-based providers in offering extended care as a form of informal support network for families and personal support beyond their primary role as caregivers. Research by Bromer and Henly (2009) suggests that home-based providers function as valuable informal resources for parents and as an important extension of parents' social and family networks, even as they recognise that the nature of such a network remains relatively unexplored. Phrases such as "sustained partnership", "personal, ongoing consistent relationship" and "symbiotic relationship with parents, school and community" have been used by a number of authors to suggest an ecological, nested system of relationships between the home-based carer and families (Bromer and Henly 2004; Garrity and McGrath 2011; Kontos 1994; Powell 1987; Rusby et al. 2013). In addition, Bromer and Henly (2009) acknowledge there is limited knowledge about home-based, or indeed center-based providers' own perceptions of their role in terms of family support and responsibilities, as well as their expectations of the kinds of activities that form the scope of their work with the children and families. However, the research nonetheless suggests a hallmark of homebased caregivers' role is the support relationship that they establish with parents and families, and the valuable role they play beyond just childcare.

\section{The Potential for Home-Based Childcare to Offer Children Personalised, Rich and Varied Learning}

The literature shows that home-based childcare has the potential to provide a rich and varied learning environment for young children, particularly in settings where caregivers tailor their provision to individual children's interests, and mutually defined goals are set between the parents/and caregivers for children's learning and development (Freeman and Karlsson 2012; NCB 2011). Reporting on Swedish and American data, Freeman and Karlsson (2012) present a collection of observation vignettes which show that home-based childcare "hold[s] potential for high-quality learning" (81) although such programmes often lack the recognition and support more commonly accorded to centre-based childcare. They 
contend that "home-based educare" (p. 88) offers opportunities for strong development and learning, while at the same time recognising the need for debate about what the home-based learning environment would entail and whether or not it is based on sound early childhood theory and principles. Fauth et al. (2012) note that "[b]y and large, childminders were aware of the kind of learning opportunities that should be provided to children to promote their development and learning" although in practice, they achieved varying degrees of success.

Mooney and Statham's (2003) cross-national comparative research reported on home-based provision across ten countries encompassing western and central Europe, New Zealand, Australia, the US and Britain. Such services are shown in these reports to play a significant role in providing a positive early experience for children. A consensus among the contributors is that home-based childcare not only serves as a major source of care for working parents but offers a potential source of education and learning opportunities for children and their families. However, the variations across countries in terms of how early years services are governed limits any generalisation of the findings. Bromer and Henly (2004) make a similar point about the potential for home-based childcare to engage children in rich and holistic learning. These authors maintain that when comparing centre- and home-based childcare, more positive caregiving in terms of adult-child interactions and support for children's learning was found in home-based care for infants and toddlers below preschool age, although the results were less positive for children in the older group.

\section{Continuity of Care Between Home-School-Family- Community}

A third key theme to emerge from the literature review pertains to the continuity of care and consistency provided by a single caregiver, and the potential for home-based providers to develop close relationships and connections between the home, pre/school, family and community for the benefit of the child. Whereas early studies (Mayall and Petrie 1983a, b; Moss and Brannen 1987; Petrie 1984) showed that children attending home-based care experienced a good deal of discontinuity and change, more recent research indicates much greater continuity of care for young children and their families.

This literature review suggests that home-based childcare appears to play a pivotal role in supporting children's transitions and connections from preschool to primary school or from home to preschool and school environments. A small-scale study by Coplan et al. (2010) in Canada found that children who attended home-based child care showed less anxiety when starting primary school than children who attended centre-based care. An Australian study (Bowes et al. 2009) focusing on the transition between preschool and the first year of school reported similar findings in that home-based childcare provided useful support for children during their transition years. Within the UK, research on home-based childcare needs to be considered against the backdrop of ongoing policy developments. A report on childcare provision covered by Sure Start indicated that a key point about home-based provision is the continuity of personalised care, in terms of support "from babyhood right through to school-age, and supporting their development, learning and play" (DfES, 2004, p. 30). This distinctive provision has the potential to create a positive early learning experience for young children.

\section{Gaps in the Literature}

At the start of this paper, we argued that there is a strong case for a research agenda to further investigate effective practices for home-based childcare provision. The literature review recognises the developing knowledge base but also points out the gaps and opportunities for future research. The review revealed limited information about how childminding provision might be assessed, how it links with child outcomes, and how children experience their home-based setting. In addition, the studies are often limited in scope and focus within their own countryspecific and cultural contexts. The gaps in the knowledge base can be construed in terms of three key themes.

\section{Assessing Caregiver Practices and Home-Based Childcare Quality}

While the majority of research studies indicate a general consensus about the value of a home-based early years environment, there is less agreement on what such a positive experience might look like or how such an environment may be conceived in practice. This is especially the case as home-based care providers vary in terms of their demographic profiles, levels of training, and perceived values and approaches to child care and education. The variability across settings and diversity among providers makes it difficult to generalise about practices and trends from the datasets, and so caution is needed when attempting to draw generalisations from the research. The existing literature also provides limited evidence about the quality of home-based caregiver practices and the longterm associations between home-based care experiences and children's outcomes.

One difficulty in assessing this association is the lack of a clear understanding of what a "quality" home-based childcare environment may entail. Owen (2003) asserts that 
"the question of how to decide on what counts as quality" (p. 148) is inherently problematic, particularly in homebased care. While the literature describes the potential for some home-based practices to influence children's experiences in a positive way, variations in findings and contexts make it difficult to provide a clear cut, empirically solid definition of a "quality" home-based environment. The issue of what constitutes "quality" in terms of children's developmental outcomes, child-caregiver relationship, caregiver characteristics, children's experience or other "process" factors remains contentious, although it has long been acknowledged that a new approach is needed in assessing "quality" beyond child development outcomes and other standardised measures (Harms and Clifford 1989; Monroe and Dunn 1999; Owen 2003).

One explanation for the divergence in findings may be the major differences in data sets, methodology, and sampling strategies across the studies reviewed. Some studies were based on a particular cross-section of data, whereas others were much wider and longitudinal in scale and focus. Research investigations with different methods inevitably give rise to discrepant findings. Moreover, most studies used samples that were not representative of larger populations, with significant variations in confounding variables and effect sizes, as well as location and contexts in which the studies were undertaken, thereby limiting their external validity. A key gap in the knowledge base relates to assessment measures, especially given the absence of a precise definition of what a "quality" home-based environment entails. As Rusby et al. (2013) state, "Unfortunately, quality of childcare has become an umbrella term without a clear, empirically supported definition." (p. 2); highlighting that a current challenge in the field is the lack of adequate measures of child care quality. The lack of comparable data is therefore a major limitation when reviewing the literature and careful consideration is needed when interpreting the findings.

\section{Relationship Between Home-Based Childcare and Children's Outcomes}

In a fast-changing early childhood landscape typified by limitations in finding a consensus as to what quality entails, the associations between home-based childcare and children's long term development and outcomes require further exploration. Rather than considering the effects of homebased childcare as universal, the influence of variables such as culture, social class, parental expectations, caregiver and child characteristics have to be taken into account when analysing relationships between quality of the environment and children's outcomes; and more specifically in regards to specific areas of development (e.g. social, language, communication, early literacy).
Forry et al. (2013) argue that, from a research methodology standpoint, it is notoriously difficult to collect evidence on impact and outcomes of quality (Forry et al. 2013). Research shows that the empirical evidence for the effects of childminding and home-based practices is inherently mixed. While some research shows that homebased childcare with its small group and intimate setting provides more opportunities for positive interactions between caregivers and children, other studies reveal lower child-adult interactions; often showing ambivalent or at best small moderating effects on development (Bigras et al. 2010; NCB 2011). The potential effects of home-based childcare also vary for younger and older children, and according to the age mix of the group (Kryzer et al. 2007).

The mixed results about outcomes for children contribute to the argument for further research into the interplay of factors such as the setting's characteristics, caregivers' behaviours and children's engagement in order to understand the complicated and contextual nature of young children's care and education experience in homebased settings. An implication from this literature review is therefore needed to provide evidence and articulate the distinctive dimensions of home-based settings compared to centre-based provision. Research data also are needed to explore the impact of differences in terms of the flexibility, intimacy and personalised type of services. In sum, a crucial area which warrants closer investigation is the ways in which home-based childcare provides a pedagogical approach to children's developmental and educational outcomes that is distinct from other types of childcare.

\section{Children's Everyday Experiences in Childminding and Similar Home-Based Settings}

Studies which focus directly on children's everyday experiences and their perceptions of home-based settings are relatively sparse. With the exception of a handful of country-specific studies, children's experiences and voices are seldom found in the research (Hoskins et al. 1999; Huttunen 1992; Kryzer et al. 2007; Weinberger 2006). Out of the 278 documents identified from the database search, only 22 relate directly to children's experiences in a homebased childminding context. The rather limited information on the nature of children's experiences in childminding settings suggests the need for further research on homebased practices. This review therefore identifies children's voices and experiences as an important direction for future research. Although some research has indicated the potential for home-based experiences to be an effective form of provision, the meaningful connections which occur between children and childminders are not prominent in the literature. If childminding, as a model of practice, is encapsulated within a holistic, ecological framework as 
some of the literature appears to suggest, then a closer examination of children's perspectives on their experiences will undoubtedly provide valuable insights into the culture and nature of home-based childcare. It also raises the possibility of identifying a particular type of ecology or key elements that are distinctive to the nature of home-based childcare, and how it varies across specific cultural contexts and reflecting local and national influences.

\section{Conclusion}

The focus of this research was to identify knowledge and insights into home-based childcare and how such settings contribute to the care and education of children. The database search reveals emerging research on such childcare practices, but, in general, rather limited information on the characteristics of the home-based childcare environment, and the differences between home-based and centre-based childcare. There is little evidence on the day-to-day interactions that occur in home-based settings focusing on children's experiences and from the perspective of children. Yet, home-based childcare remains an integral, almost indispensable childcare service in many societies around the world as more parents with young children at all income levels enter the labour force. As the demand for high quality, accessible, and affordable childcare grows, so does the importance of evidencing the practices of home-based childcare and its impact.

Open Access This article is distributed under the terms of the Creative Commons Attribution 4.0 International License (http://crea tivecommons.org/licenses/by/4.0/), which permits unrestricted use, distribution, and reproduction in any medium, provided you give appropriate credit to the original author(s) and the source, provide a link to the Creative Commons license, and indicate if changes were made.

\section{Appendix: Summary of Selected Literature on Home-Based Childcare}

\begin{tabular}{|c|c|c|c|c|}
\hline $\begin{array}{l}\text { Author/s } \\
\text { and } \\
\text { citation }\end{array}$ & $\begin{array}{l}\text { Type of } \\
\text { publication }\end{array}$ & Aims of study & Methodology & Findings \\
\hline $\begin{array}{l}\text { Bowes } \\
\text { et al. } \\
(2009)\end{array}$ & $\begin{array}{c}\text { Research } \\
\text { report }\end{array}$ & $\begin{array}{l}\text { To investigate the child care and early } \\
\text { school experiences of children in } \\
\text { urban and rural New South Wales, } \\
\text { Australia, focusing on children's } \\
\text { child care experience and the } \\
\text { associations with children's } \\
\text { adjustment to school and } \\
\text { achievements }\end{array}$ & $\begin{array}{l}\text { Mixed-methods design using } \\
\text { telephone interviews with parents, } \\
\text { questionnaire surveys with } \\
\text { providers and teachers, and } \\
\text { observations in long day care } \\
\text { centres, family day care homes, } \\
\text { preschools and Kindergarten }\end{array}$ & $\begin{array}{l}\text { Child care experiences play an } \\
\text { important part in preparing children } \\
\text { for the transition to school. Aspects } \\
\text { of children's care history, family } \\
\text { factors and, to a lesser extent, child } \\
\text { care quality characteristics are } \\
\text { associated with children's } \\
\text { achievement and adjustment during } \\
\text { transition }\end{array}$ \\
\hline $\begin{array}{l}\text { Bromer } \\
\text { and } \\
\text { Henly } \\
\text { (2009) }\end{array}$ & $\begin{array}{r}\text { Journal } \\
\text { article }\end{array}$ & $\begin{array}{l}\text { To develop a conceptual framework } \\
\text { for childcare practices, especially } \\
\text { for providers serving low-income } \\
\text { families; focusing on the range of } \\
\text { family support roles offered by } \\
\text { childcare providers in center-based } \\
\text { and home-based child care }\end{array}$ & $\begin{array}{l}\text { Content analysis of empirical research } \\
\text { and theoretical underpinnings; The } \\
\text { authors argue the case for } \\
\text { conceptualising home-based } \\
\text { childcare as a form of family } \\
\text { support }\end{array}$ & $\begin{array}{l}\text { There are several factors that shape } \\
\text { the roles of childcare providers } \\
\text { including type of setting, provider's } \\
\text { level of professionalism, and } \\
\text { motivations. Non-relative family } \\
\text { childcare providers and center- } \\
\text { based providers may be better } \\
\text { placed to offer family support to } \\
\text { low-income family than the families } \\
\text { themselves }\end{array}$ \\
\hline $\begin{array}{l}\text { Bromer } \\
\text { and } \\
\text { Henly } \\
\text { (2009) }\end{array}$ & $\begin{array}{r}\text { Journal } \\
\text { article }\end{array}$ & $\begin{array}{l}\text { To investigate the role of child care } \\
\text { providers in supporting low-income } \\
\text { children and families in Chicago }\end{array}$ & $\begin{array}{l}\text { Qualitative analysis involving } 29 \\
\text { childcare providers. Two interviews } \\
\text { conducted with each provider } \\
\text { including a close-ended telephone } \\
\text { questionnaire and in-person semi- } \\
\text { structured interview }\end{array}$ & $\begin{array}{l}\text { Family child care providers offer a } \\
\text { range of support for low-income } \\
\text { parents with substantial logistical } \\
\text { (e.g. flexible child care hours) and } \\
\text { economic (e.g. reduced fees) help, } \\
\text { in addition to direct care and } \\
\text { education of their children }\end{array}$ \\
\hline $\begin{array}{l}\text { Colwell } \\
\text { et al. } \\
(2013)\end{array}$ & $\begin{array}{l}\text { Journal } \\
\text { article }\end{array}$ & $\begin{array}{l}\text { To assess the psychometric properties } \\
\text { of the Arnett Caregiver Interaction } \\
\text { Scale (CIS) which measures the } \\
\text { quality of caregiver-child } \\
\text { interactions }\end{array}$ & $\begin{array}{l}\text { Quantitative analysis using stratified } \\
\text { random sampling focusing on a sub- } \\
\text { group of 2-4 year olds in home- } \\
\text { based and center-based childcare. } \\
\text { Sample included } 750 \text { home-based } \\
\text { providers and } 1350 \text { center-based } \\
\text { providers at } 4 \text { years }\end{array}$ & $\begin{array}{l}\text { Arnett CIS is not well suited to } \\
\text { distinguish between caregivers who } \\
\text { are highly or moderately positive in } \\
\text { their caregiver-child interactions. } \\
\text { The association between the Arnett } \\
\text { CIS and child outcomes are } \\
\text { relatively small, especially for } \\
\text { children in center-based childcare }\end{array}$ \\
\hline
\end{tabular}


continued

\begin{tabular}{|c|c|c|c|c|}
\hline $\begin{array}{l}\text { Author/s } \\
\text { and } \\
\text { citation }\end{array}$ & $\begin{array}{l}\text { Type of } \\
\text { publication }\end{array}$ & Aims of study & Methodology & Findings \\
\hline $\begin{array}{l}\text { Fauth et al. } \\
\text { (2012) }\end{array}$ & $\begin{array}{l}\text { Research } \\
\text { report }\end{array}$ & $\begin{array}{l}\text { To assess aspects of childminding } \\
\text { practices in England; } \\
\text { Childminders' views and } \\
\text { understanding of children's } \\
\text { learning and development }\end{array}$ & $\begin{array}{l}\text { Mixed-methods study, based on a } \\
\text { survey, interviews and } \\
\text { observations with } 581 \\
\text { childminders' }\end{array}$ & $\begin{array}{l}\text { Key elements that constitute } \\
\text { effective childminding practice } \\
\text { include links between caring and } \\
\text { learning, flexibility of provision, } \\
\text { and providing a service for working } \\
\text { parents }\end{array}$ \\
\hline $\begin{array}{l}\text { Forry et al. } \\
\text { (2013) }\end{array}$ & $\begin{array}{l}\text { Journal } \\
\text { article }\end{array}$ & $\begin{array}{l}\text { To examine the correlation between } \\
\text { provider characteristics and quality } \\
\text { practices in family childcare } \\
\text { serving children } 2.5-5 \text { years }\end{array}$ & $\begin{array}{l}\text { Mixed method design involving } 182 \\
\text { providers and } 451 \text { children }\end{array}$ & $\begin{array}{l}\text { Provider characteristics indicative of } \\
\text { personal and professional } \\
\text { resources, professional attitudes } \\
\text { and beliefs are predictors of } \\
\text { observed quality measures } \\
\text { Some associations found between } \\
\text { providers' attitudes and beliefs, and } \\
\text { children's developmental outcomes }\end{array}$ \\
\hline $\begin{array}{l}\text { Freeman } \\
\text { and } \\
\text { Karlsson } \\
(2012)\end{array}$ & $\begin{array}{l}\text { Journal } \\
\text { article }\end{array}$ & $\begin{array}{l}\text { To explore home-based childcare } \\
\text { providers' narratives that illustrate } \\
\text { positive continuity with parents } \\
\text { and schools }\end{array}$ & $\begin{array}{l}\text { Qualitative design using narrative } \\
\text { inquiry involving four participants }\end{array}$ & $\begin{array}{l}\text { All participants/family childcare } \\
\text { providers maintained strong inter- } \\
\text { connections with the children, } \\
\text { schools, families and communities; } \\
\text { Participants provided education } \\
\text { and "teaching" of factual } \\
\text { knowledge and practical skills in } \\
\text { structuring activities for their } \\
\text { children in developmental domains } \\
\text { such as language, cognitive and } \\
\text { physical development }\end{array}$ \\
\hline $\begin{array}{l}\text { Fuller et al. } \\
\text { (2004) }\end{array}$ & $\begin{array}{l}\text { Journal } \\
\text { article }\end{array}$ & $\begin{array}{l}\text { To examine the differences in child } \\
\text { care quality between center-based } \\
\text { and family care settings that serve } \\
\text { poor families }\end{array}$ & $\begin{array}{l}\text { Mixed methods study involving } 166 \\
\text { centers and } 187 \text { home settings } \\
\text { (including family child care homes } \\
\text { and relative/family providers) } \\
\text { utilised by mothers on a welfare-to- } \\
\text { work programme in California }\end{array}$ & $\begin{array}{l}\text { Significant variations found in the } \\
\text { quality between home-based and } \\
\text { center-based settings. Family child } \\
\text { care homes displayed higher } \\
\text { quality provision on the Family } \\
\text { Day Care Rating Scale (FDCS) in } \\
\text { providing flexible childcare for } \\
\text { low-income mothers }\end{array}$ \\
\hline $\begin{array}{l}\text { Garrity and } \\
\text { McGrath } \\
\text { (2011) }\end{array}$ & $\begin{array}{l}\text { Journal } \\
\text { article }\end{array}$ & $\begin{array}{l}\text { To explore the issues and challenges } \\
\text { of a group of ethnic minority } \\
\text { women childminders in Ireland }\end{array}$ & $\begin{array}{l}\text { Qualitative study based on in-depth } \\
\text { interviews with twelve African } \\
\text { childminders and their experiences } \\
\text { of childcare in Ireland }\end{array}$ & $\begin{array}{l}\text { Participants placed much emphasis } \\
\text { on providing a high-quality service } \\
\text { and maintaining a professional } \\
\text { approach in their work as childcare } \\
\text { providers. Many perceive their role } \\
\text { as providing a range of family } \\
\text { support }\end{array}$ \\
\hline $\begin{array}{l}\text { Hughes- } \\
\text { Belding } \\
\text { and } \\
\text { Hegland } \\
(2012)\end{array}$ & $\begin{array}{l}\text { Academic } \\
\text { Journal } \\
\text { article }\end{array}$ & $\begin{array}{l}\text { To examine the structural } \\
\text { characteristics and provider beliefs } \\
\text { that influence quality in family } \\
\text { child care homes }\end{array}$ & $\begin{array}{l}\text { Qualitative study involving } \\
\text { interviews with and observations of } \\
257 \text { family providers. A } \\
\text { combination of the Family Day } \\
\text { Care Rating Scale (FDCRS) and } \\
\text { Caregiver Interaction Scale (CIS) } \\
\text { are used }\end{array}$ & $\begin{array}{l}\text { Structural qualities and teacher belief } \\
\text { are important indicators of the } \\
\text { quality of child care demonstrated } \\
\text { by family child care providers }\end{array}$ \\
\hline $\begin{array}{l}\text { Kryzer } \\
\text { et al. } \\
(2007)\end{array}$ & $\begin{array}{l}\text { Academic } \\
\text { Journal } \\
\text { article }\end{array}$ & $\begin{array}{l}\text { To explore toddlers (16-36 months) } \\
\text { and preschoolers ( } 42-54 \text { months) } \\
\text { experiences and behaviour in } \\
\text { family and center-based care } \\
\text { settings; To examine indicators of } \\
\text { quality in family day care practice }\end{array}$ & $\begin{array}{l}\text { Mixed methods study involving } \\
\text { observations of } 112 \text { children (56 } \\
\text { toddlers and } 56 \text { preschoolers) and } \\
\text { analysis of quality ratings in family } \\
\text { child care settings; Modified } \\
\text { version of the "Observational } \\
\text { Ratings of the Caregiving } \\
\text { Environment" (ORCE) instrument } \\
\text { is used }\end{array}$ & $\begin{array}{l}\text { Findings are inconclusive as to } \\
\text { which type of care-home-orcenter- } \\
\text { based offers a higher quality care } \\
\text { or greater benefits for children of } \\
\text { different age groups }\end{array}$ \\
\hline
\end{tabular}


continued

\begin{tabular}{|c|c|c|c|c|}
\hline $\begin{array}{l}\text { Author/s } \\
\text { and } \\
\text { citation }\end{array}$ & $\begin{array}{l}\text { Type of } \\
\text { publication }\end{array}$ & Aims of study & Methodology & Findings \\
\hline $\begin{array}{l}\text { Lekhal } \\
\text { et al. } \\
\text { (2011) }\end{array}$ & $\begin{array}{c}\text { Journal } \\
\text { article }\end{array}$ & $\begin{array}{l}\text { To examine the association between } \\
\text { the type of child care arrangement } \\
\text { for children age } 1,1.5 \text { and } 3 \text { years } \\
\text { and late talking }\end{array}$ & $\begin{array}{l}\text { Secondary data analysis of national } \\
\text { data from the Norwegian Mother } \\
\text { and Child Cohort Study (1999) } \\
\text { were used in this study }\end{array}$ & $\begin{array}{l}\text { Both family day care and centre care } \\
\text { children ( } 1.5 \text { and } 3 \text { years) show a } \\
\text { lower prevalence of late talking } \\
\text { compared to children in more } \\
\text { informal care }\end{array}$ \\
\hline $\begin{array}{l}\text { Moss and } \\
\text { Brannen } \\
(1987)\end{array}$ & $\begin{array}{l}\text { Journal } \\
\text { article }\end{array}$ & $\begin{array}{l}\text { To examine the extent and causes of } \\
\text { discontinuity in daycare provision } \\
\text { for children up to } 18 \text { months of age } \\
\text { across day care and childminding } \\
\text { settings }\end{array}$ & $\begin{array}{l}\text { Qualitative study involving a sample } \\
\text { of } 188 \text { children }\end{array}$ & $\begin{array}{l}\text { Discontinuities and changes in } \\
\text { daycare arrangements were more } \\
\text { frequent for children cared for by } \\
\text { relatives and childminders than for } \\
\text { those in day nurseries }\end{array}$ \\
\hline $\begin{array}{l}\text { Mayall } \\
\text { and } \\
\text { Petrie } \\
\text { (1983a, } \\
\text { b) }\end{array}$ & Book & $\begin{array}{l}\text { To explore the types of childcare } \\
\text { experience for children under } \\
2 \text { years old in childminding and } \\
\text { day nurseries }\end{array}$ & $\begin{array}{l}\text { Qualitative study involving } \\
\text { interviews and observations; the } \\
\text { sample included } 159 \text { childminders, } \\
64 \text { mothers of childminded children } \\
\text { and } 41 \text { nursery nurses }\end{array}$ & $\begin{array}{l}\text { Wide disparities of quality in } \\
\text { childminding, especially for } \\
\text { children in disadvantaged families; } \\
\text { there are difficulties in making } \\
\text { systematic comparisons but day } \\
\text { nurseries showed more emphasis } \\
\text { on routines with more evidence of } \\
\text { group care and purposeful activities }\end{array}$ \\
\hline $\begin{array}{l}\text { Monroe } \\
\text { and } \\
\text { Dunn } \\
\text { (1999) }\end{array}$ & $\begin{array}{l}\text { Journal } \\
\text { article }\end{array}$ & $\begin{array}{l}\text { To explore the childcare } \\
\text { environments of in-home } \\
\text { nonrelative child care providers and } \\
\text { their parents/employers }\end{array}$ & $\begin{array}{l}\text { Survey questionnaire design } \\
\text { involving } 30 \text { caregivers and } 29 \\
\text { parents/employers respondents }\end{array}$ & $\begin{array}{l}\text { Importance of the ecological context } \\
\text { of home-based nonrelative care; } \\
\text { Planned and purposeful activities } \\
\text { that are associated with good } \\
\text { quality care are not prevalent in the } \\
\text { settings; new strategies for } \\
\text { assessing quality home-based child } \\
\text { care need to be further explored }\end{array}$ \\
\hline $\begin{array}{l}\text { Owen } \\
(2003)\end{array}$ & $\begin{array}{l}\text { Research } \\
\text { review }\end{array}$ & $\begin{array}{l}\text { To evaluate the issue of measuring } \\
\text { and assessing quality in } \\
\text { childminding }\end{array}$ & $\begin{array}{l}\text { A review paper with a critical } \\
\text { discussion of the research around } \\
\text { childminding }\end{array}$ & $\begin{array}{l}\text { Issue of quality is particularly } \\
\text { contentious within child-minding; } \\
\text { the need for a new approach to } \\
\text { assessing quality beyond } \\
\text { measurements of child } \\
\text { development outcomes }\end{array}$ \\
\hline $\begin{array}{l}\text { Ota and } \\
\text { Austin } \\
(2013)\end{array}$ & $\begin{array}{l}\text { Journal } \\
\text { article }\end{array}$ & $\begin{array}{l}\text { To examine the effectiveness of two } \\
\text { professional development models } \\
\text { of family child care providers' } \\
\text { support of children's early } \\
\text { language development }\end{array}$ & $\begin{array}{l}\text { Quantitative framework using } \\
\text { intervention and control groups. } \\
\text { Providers and children } 0-5 \text { years at } \\
48 \text { family child care programmes } \\
\text { participated in the study }\end{array}$ & $\begin{array}{l}\text { Both forms of professional } \\
\text { developments models increased } \\
\text { linguistic stimulation of children. } \\
\text { Increased effectiveness on } \\
\text { children's language development } \\
\text { was found when professional } \\
\text { development included in-service } \\
\text { training and on-site mentoring of } \\
\text { family child care providers }\end{array}$ \\
\hline $\begin{array}{l}\text { Petrie } \\
\quad(1984)\end{array}$ & $\begin{array}{c}\text { Journal } \\
\text { article }\end{array}$ & $\begin{array}{l}\text { To examine the quality of day care } \\
\text { for children under } 2 \text { at child } \\
\text { minders and in day nurseries }\end{array}$ & $\begin{array}{l}\text { Qualitative study involving } \\
\text { interviews with } 159 \text { childminders; } \\
66 \text { childminders for under 2's were } \\
\text { further selected; Mothers of the } \\
\text { under 2's were also interviewed } \\
\text { and observed with their children; } \\
\text { Nursery officers and officers in } \\
\text { charge were interviewed in } 15 \\
\text { London day nurseries }\end{array}$ & $\begin{array}{l}\text { Quality of childminding was } \\
\text { variable, particularly for } \\
\text { disadvantaged mothers; There was } \\
\text { an association between the } \\
\text { mother's social class and the } \\
\text { quality rating of the childminder }\end{array}$ \\
\hline
\end{tabular}


continued

\begin{tabular}{|c|c|c|c|c|}
\hline $\begin{array}{l}\text { Author/s } \\
\text { and } \\
\text { citation }\end{array}$ & $\begin{array}{l}\text { Type of } \\
\text { publication }\end{array}$ & Aims of study & Methodology & Findings \\
\hline $\begin{array}{l}\text { Rusby } \\
\text { et al. } \\
\text { (2013) }\end{array}$ & $\begin{array}{l}\text { Journal } \\
\text { article }\end{array}$ & $\begin{array}{l}\text { To investigate the reliability and } \\
\text { validity of the Child Care Ecology } \\
\text { Inventory (CCEI) to measure the } \\
\text { quality of family child care within a } \\
\text { social domain }\end{array}$ & $\begin{array}{l}\text { Mixed method using combined data } \\
\text { from two existing studies. Study } 1 \\
\text { involved } 64 \text { child care homes and } \\
\text { study } 2 \text { involved a sample of } 134\end{array}$ & $\begin{array}{l}\text { Different aspects of quality are related } \\
\text { to different aspects of children's } \\
\text { social interactions and behaviours; } \\
\text { Caregivers' provision of planned } \\
\text { activities and positive attention } \\
\text { were associated with positive child } \\
\text { behaviour and social skills }\end{array}$ \\
\hline $\begin{array}{l}\text { Tonyan } \\
\text { and } \\
\text { Nuttall } \\
\text { (2014) }\end{array}$ & $\begin{array}{l}\text { Journal } \\
\text { article }\end{array}$ & $\begin{array}{l}\text { To examine the cultural organisation } \\
\text { and influences of childminding, and } \\
\text { the daily routines and career paths } \\
\text { of childminders }\end{array}$ & $\begin{array}{l}\text { Quantitative method using a survey } \\
\text { design. This is a pilot study of } 22 \\
\text { respondents }\end{array}$ & $\begin{array}{l}\text { Childminders' daily routines were } \\
\text { related to cultural models of } \\
\text { practices in different local contexts; } \\
\text { an ecological-cultural theoretical } \\
\text { model was piloted and found to be } \\
\text { useful in conceptualising the } \\
\text { diversity of childminding work }\end{array}$ \\
\hline
\end{tabular}

\section{References}

Arnett, J. (1989). Caregivers in day-care centers: Does training matter? Journal of Applied Developmental Psychology, 10(4), $541-552$.

Bigras, N., Bouchard, C., Cantin, G., Brunson, L., Coutu, S., Lemay, L., et al. (2010). A comparative study of structural and process quality in center-based and family-based child care services. Child and Youth Care Forum, 39(3), 129-150.

Bowes, J., Harrison, L., Sweller, N., Taylor, A., \& Neilsen-Hewett, C. (2009). From child care to school: Influences on children's adjustment and achievement in the year before school and the first year of school. Findings from the childcare choices Longitudinal Extension study. Research report to the NSW Department of Communities Services, New South Wales.

Bromer, J. (2002). Extended care: Family child care as family support and community development in low income neighborhoods. Zero to Three, 23(2), 33-37.

Bromer, J., \& Henly, J. (2004). Child care as family support: Caregiving practices across child care providers. Children and Youth Services Review, 26, 941-964.

Bromer, J., \& Henly, J. (2009). The work-family support roles of child care providers across settings. Early Childhood Research Quarterly, 24, 271-288.

Colwell, N., Gordon, R. A., Fujimoto, K., Kaestner, R., Korenman, S., et al. (2013). New evidence on the validity of the Arnett Caregiver Interaction Scale: Results from the early childhood longitudinal study-birth cohort. Early Childhood Research Quarterly, 28, 218-233.

Coplan, R., Findlay, L. C., \& Schneider, B. H. (2010). Where do anxious children "fit" best? Childcare and the emergence of anxiety in childhood. Canadian Journal of Behavioural Science, 42, 185-193. doi:10.1037/a0019280.

Department for Education (DfES). (2004). Sure start. Working together, http://webarchive.nationalarchives.gov.uk/2013040115 1715/https://www.education.gov.uk/publications/eOrderingDown load/SSWT0304PDF.pdf.
Department for Education (DfE). (2013). More great childcare. Raising quality and giving parents more choice. https://www. gov.uk/government/uploads/system/uploads/attachment_data/file/ 219660/More_20Great_20Childcare_20v2.pdf.

Doherty, G., Lero, D. S., Goelman, H., Tougas, J., \& LaGrange, A. (2000). Caring and learning environments: Quality in regulated family child care across Canada. Canada, ON: Centre for Families, Work and Well-Being, University of Guelph.

Fauth, R., Owen, S., \& Jelicic, H. (2012). The next best thing to being at home: Parents' view of quality in home-based childcare settings. Research summary. London: NCB Research Centre.

Forry, N., Iruka, I., Tout, K., Torquati, J., Susman-Stillman, A., Bryant, D., et al. (2013). Predictors of quality and child outcomes in family child care settings. Early Childhood Research Quarterly, 28, 893-904.

Freeman, R., \& Karlsson, M. (2012). Strategies for learning experiences in family child care: American and Swedish perspectives. Childhood Education, 88(2), 81-90.

Fuller, B., Kagan, S. L., Loeb, S., \& Chang, Y. W. (2004). Child care quality: Centers and home settings that serve poor families. Early Childhood Research Quarterly, 19, 505-527.

Garrity, S., \& McGrath, B. (2011). "It's not like a job now; It's Part of me": Exploring African Women's experiences in the Irish Childcare Sector. Child Care in Practice, 17(1), 69-86.

Gough, D., Oliver, S., \& Thomas, J. (2012). An introduction to systematic reviews. London: Sage.

Harms, T., \& Clifford, R. M. (1989). Family day care rating scale. New York, NY: Teachers College Press.

Hoskins, M., Pence, A., \& Chambers, E. (1999). Quality and day care: What do children have to say? Early child Development and Care, 157, 51-66.

Hughes, R. (1985). The informal help-giving of home and center childcare providers. Family Relations, 34, 359-366.

Hughes-Belding, K., \& Hegland, S. (2012). Predictors of global quality in family child care homes: Structural and belief characteristics. Early Education and Development, 23, 697-712.

Huttunen, E. (1992). Children's experiences in early childhood programmes. International Journal of Early Childhood, 24(2), 3-11. 
Koh, S., \& Neuman, S. (2009). The impact of professional development in family child care: A practice-based approach. Early Education and Development, 20(3), 537-562.

Kontos, S. (1994). The ecology of family day care. Early Childhood Research Quarterly, 9, 87-110.

Kryzer, E., Kovan, N., Phillips, D. A., Domagall, L. A., \& Megan, R. G. (2007). Toddlers' and preschoolers' experience in family day care: Age differences and behavioural correlates' children. Early Childhood Research Quarterly, 22, 451-466.

Lekhal, R., Zachrisson, H., Wang, M. V., Schjølberg, S., \& Soest, T. (2011). Does universally accessible child care protect children fromlate talking? Results from a Norwegian population-based prospective study. Early Child Development and Care, 181(8), 1007-1019.

Mayall, B., \& Petrie, P. (1983a). Childminding and day nurseries: What kind of care? London: Heinemann.

Mayall, B., \& Petrie, P. (1983b). Child-minding and day nurseries: What kind of care? Heinemann: University of London, Institute of Education.

Monroe, L., \& Dunn, L. (1999). The ecological context of in-home nonrelative child care. Early Child Development and Care, 157, $7-26$.

Mooney, A., \& Statham, J. (Eds.). (2003). Family day care: International perspectives on policy, practice and quality. London, New York: Jessica Kingsley Publishers.

Moss, P., \& Brannen, J. (1987). Discontinuity in daycare arrangements for very young children. Early Child Development and Care, 29, 435-449.

National Children's Bureau. Research Centre. (2011). Childminding practice in England'. http://www.ncb.org.uk/media/891898/ncb_ rsch_summ_10_final.pdf.

National Institute of Child Health and Human Development Early Child Care Research Network (NICHD). (2000). Characteristics and quality of child care for toddlers and preschoolers. Applied Developmental Science, 4, 116-135.

OECD. (2006). Starting strong II: Early childhood education and care. Paris: OECD. http://www.oecd.org/edu/school/starting strongiiearlychildhoodeducationandcare.htm.

OECD. (2012). Starting strong III: A quality toolbox for early childhood education and care. Paris: OECD. http://www.oecd. org/edu/school/startingstrongiii-aqualitytoolboxforearlychildhoo deducationandcare.htm.

Ota, C., \& Austin, A. (2013). Training and mentoring: Family childcare providers' use of linguistic inputs in conversations with children. Early Childhood Research Quarterly, 28, 972-983.

Owen, S. (2003). The development of childminding networks in Britain: Sharing the caring. In A. Mooney \& J. Statham (Eds.), Family day care: International perspectives on policy, practice and quality. London, New York: Jessica Kingsley Publishers.

Petrie, P. (1984). Day care for under 2's at childminders and in day nurseries. Early Childhood Development and Care, 16, 205-216.

Policy Exchange. (2013). Quality childcare. Improving early years childcare. London: Policy Exchange. http://www.policyex change.org.uk/images/publications/quality\%20childcare.pdf.

Powell, D. (1987). Day care as a family support system. In S. L. Kagan, D. R. Powell, B. Weissbourd, \& E. F. Zigler (Eds.), America's family support programs: The origins and development of a movement. New Haven, CT: Yale University Press.

Rusby J. C., Jones L. B., Crowley R., Smolkowski K. (2013). The Child Care Ecology Inventory: A domain-specific measure of home-based childcare quality to promote social competence for school readiness. Early Childhood Research Quarterly, 28, $1-13$.

Sylva, K., Melhuish, E., Sammons, P., Siraj-Blatchford, I., \& Taggart, B. (2004). The final report: Effective pre-school education, Technical Paper 12. London: Institute of Education and DfES.

Tonyan, H., \& Nuttall, J. (2014). Connecting cultural models of home-based care and childminders' career paths: An eco-cultural analysis. International Journal of Early Years Education, 22(1), $117-138$.

UNESCO. (2007). Strong foundations-Early childhood care and education. Paris: UNESCO. http://unesdoc.unesco.org/images/ 0014/001477/147794e.pdf.

UNESCO. (2014). EFA Global Monitoring report. Teaching and learning: Achieving quality for all 2013-2014. http://unesco.nl/ sites/default/files/dossier/gmr_2013-4.pdf?download=1.

Weinberger, N. (2006). Children's use of retreats in family child care homes. Early Education and Development, 17(4), 571-591. 